Teresa Maria Grabowska

University of Warsaw

teresa.grabowska6@gmail.com

\title{
Edward August Landié, author of Polish coursebooks for French language teaching, and Samuel Orgelbrand, his publisher
}

\begin{abstract}
The article presents Edward Landié (1788-1853), author of popular coursebooks for French language teaching, and its publisher, Samuel Orgelbrand (1810-1868), who highly contributed to the development of the book market in the Kingdom of Poland, in the years 1840-1868. Landié was of French origin and Orgelbrand - of a Jewish one. Both started their activities in Warsaw in the years 1829-1930. E. Landié reached the high position of the Warsaw French language teacher and became an outstanding author of coursebooks. S. Orgelbrand managed an outstanding Warsaw publishing house. Their cooperation is an example of a significant contribution of different environments into the development of education and culture not only in Warsaw but the whole trapped Poland.
\end{abstract}

Keywords: Eward Landié - coursebooks for the French language teaching - Samuel Orgelbrand editorship - Warszawa - Kingdom of Poland $-19^{\text {th }}$ century.

„Z Badań nad Książką i Księgozbiorami Historycznymi” - Udział zagranicznych recenzentów w ocenie publikacji; Stworzenie anglojęzycznej wersji wydawniczej publikacji; Digitalizacja tomów archiwalnych rocznika w celu zapewnienia otwartego dostępu do nich przez Internet oraz wdrożenie i utrzymanie cyfrowej platformy redakcyjnej - zadanie finansowane w ramach umowy nr 653/P-DUN/2019 ze środków Ministra Nauki i Szkolnictwa Wyższego przeznaczonych na działalność upowszechniającą naukę. 
Political events at the end of the $18^{\text {th }}$ and the first half of the $19^{\text {th }}$ century was a breakthrough in the history of Europe. The French Revolution, Napoleon wars, the Vienna Congress, restitution of the Empire created a new order of the world ${ }^{1}$. These political changes were accompanied by the industrial revolution, as well as economic and social changes. All that influenced the fates of individual persons ${ }^{2}$.

This text concerns Edward August Ewadiusz Landié (1788-1853) and Samuel Orgelbrand (1810-1868), who lived in this dynamically changing epoch $^{3}$. The former was of French origin, emigrant, who found a safe haven for himself and his family in Warsaw. The latter was a Warsaw Jew, who spend there his entire life. Landié was the author of coursebooks for French language teaching, and Orgelbrand - their publisher. Both became masters in their professions. They were joined by a cult of work, enabling prosperous life, the beneficiary of which was also the Polish society.

Manuscript and printed sources of the years 1814-1897, stored in the National Library of Poland (Biblioteka Narodowa - BN), the University of Warsaw Library (Biblioteka Uniwersytecka w Warszawie - BUW), as well materials from the Municipal Archives et Agen (France) for the years 17881814 were used for developing this contribution to biographies of both men.

E. Landié was born in the city of Agen, Lot-et-Garonna department in France in the year 1788, from the parents Joseph Landié and Felicia de Lasvennes. Father was the owner of vineyards and real estate ${ }^{4}$. As a boy, E. Landié learned in a local college and a monastery nearby. He lost his father at the age of sixteen. His mother released him to a cousin - marshal Jean Baptiste Bessières ${ }^{5}$, prince of Istria. Young Landié went to the elite Paris Military School, and to divisions of Imperial Guard, so-called Velites ${ }^{6}$. This unit accepted young men, with excellent health, height over $173 \mathrm{~cm}$, appropriate education and good background. After graduation in the rank of second lieutenant, E. Landié took part in the fights in Germany, and in the Spain campaign. After that, he lost most of his properties and was forced to leave the officer's condition. When he returned to civil life, he started medical studies, which was to ensure his

\footnotetext{
Historia Europy, pod red. A. Mączaka, Wrocław 1997, pp. 492-504.

2 See e.g. Historia życia prywatnego. Vol. 4: Od rewolucji francuskiej do I wojny światowej, ed. by M. Perrot, study by A. Corbin [et al.]; translated from French language by A. Paderewska-Gryza, B. Panek, W. Gilewski, scientific edition of translation of the $4^{\text {th }}$ volume M. Czapliński, Wrocław 2006.

3 The article is related to the Ph.D. dissertation being preared by the author: Edward August Landié i rola jego publikacji w nauczaniu języka francuskiego w Królestwie Polskim.

4 Municipal Archives et Agen, sign. 3Q1/10/1, Collection of parchment documents, unnumb. sheet.

5 R. Bielecki, Wielka armia Napoleona, $2^{\text {nd }}$ edition revised and completed, Warszawa 2004, pp. 222-232.
}

6 Idem, Encyklopedia wojen napoleońskich, Warszawa 2002, p 201. 
financial prosperity and stability in the future. Among others, he attended courses run by such famous professors as Antoine Dubois, Joseph-Claude-Anthelme Récamier, Jean-Nicolas Marjolin, and others ${ }^{7}$. After graduation, he became a successful Parisian physician. He spoke perfectly Latin, Italian, and German. Moreover, he was deeply interested in literature and philosophy ${ }^{8}$, as wrote "Kurier Warszawski" ("Warsaw Courier"):

W chwilach wolnych od zatrudnień nowego swojego zawodu, wydał kilka dzieł literackich. Pomiędzy innemi, w roku 1815, Historja moralna Wymowy[[], której dedykacją przyjąć raczył, znakomity ówczasowy Mąż stanu, Regnault [właśc. Regnaud] de St. Jean d'Angely ${ }^{10}$. (In the time free from his new employment, he published several literary works. Among others, Historja moralna Wymowy in 1815, with dedication accepted by an outstanding statesman od that time, Regnault [correct. Regnaud] de St. Jean d'Angely).

E. Landié left Paris during the anti-republican events of November 1829, which could have influenced his fate ${ }^{11}$. He left France, fearing the governing of prince Julesade Polignac, who - according to a part of the French society represented the most anti-democratic and anti-liberal government since the revolution of $1789^{12}$. As a libertine and Bonapartist, E. Landié realized that Charles the 10th reign in France would restrain democracy and liberalism. He also felt responsible for the safety of his family. Therefore he was looking for a more quiet and safe place for living for their family, and work for himself.

Poland, which disappeared from the map of Europe at the end of the $18^{\text {th }}$ century, was a particularly attractive place for foreigners, welcomed either by the invaders or the Poles themselves. Immigrants from different countries easily became assimilated and co-created Polish culture under partition. Napoleon's army came to the Polish territory at the beginning of the $19^{\text {th }}$ century, and the emperor Napoleon Bonaparte established the Duchy of Warsaw, on a French model ${ }^{13}$, awakening hopes for regaining independence by Poland.

See e.g. G. Androutso [et al.], Joseph-Claude-AnthelmeRécamier (1774-1852): forerunner in surgical oncology, "Journal of BUON" 2011, vol. 16, pp. 572-576, [online] https://www.researchgate.net/publication/51721295_Joseph-Claude-Anthelme_Recamier_1774-1852_Forerunner_in_surgical_oncology [retrieved on 24.05.2018].

Edward August Landié, "Kurier Warszawski" 1853, no. 164, p. 825.

9 Actually, the first edition was published in 1813 in 100 copies, and the second in 1814 in Paris, titled Histoire morale de l'éloquence, ou développements historiques sur l'intelligence et le goùt, par rapport à l'éloquence, see: J.-C. Brunet, Manuel du libraire et de l'amateur de livres... [Vol. 5], Bruxelles 1845, p. 222 . The copy of the $2^{\text {nd }}$ edition of this publication is stored in the University of Warsaw Library, sign. BUW 11.3.8.152.

10 Regnaud de Saint-Jean d'Angély,Auguste Comte, [online] https://www.napoleon.org/en/history-of-the-two-empires/biographies/regnaud-de-saint-jean-dangely-auguste-comte/ [retrieved on 10.10.2018].

11 J. Cabanis, Karol X. Król-ultras, transl. W. Dłuski, Warszawa 1981, p. 361.

12 Ibidem, p. 362.

13 P. Cichoń, Wpływy francuskie w administracji Księstwa Warszawskiego, "Zeszyty Naukowe 
The Frenchmen in a larger number joined the group of Warsaw inhabitants of nationality other than Polish, mostly Jews and Germans ${ }^{14}$. No wonder that the Landié family council decided that settling in the far Kingdom of Poland, in its capital Warsaw, would be the safest for them. Well educated and well-off cousins and relatives of the Landié family lived there and praised their stay, they also offered them support, indispensable at the beginning ${ }^{15}$. Among them, there was his close relative and friend general Piotr Karol (Pierre Charles) Bontemps, who after Napoleon's fall took up a position of director of Artillery Materials and Arsenal in the Artillery Corps and Engineers of the Kingdom of Poland ${ }^{16}$. They both belonged to the masonic lodge - Grand Orient of France (Grand Orient de France) and had high degrees of initiation and decorations for the masonic service.

E. Landié arrived in Warsaw in November 1829, in the moment of patriotic and independent atmosphere among the Poles, a year before the November Uprising ${ }^{17}$. He hoped for work as a physician, however complete ignorance of the Polish language deprived him of this possibility. Therefore he devoted himself to teaching, which he was passionate about, also due to earlier literary works. As a lecturer of French literature and language ${ }^{18}$, he began his work in Instytut Rządowy Wychowania Płci Żeńskiej (The Government Institute of Women Education), commonly known as Instytut Guwernantek (The Institute for Governesses) in 1829. Just in 1830, he became a secretary for French correspondence in Komisja Rządowa Spraw Wewnętrznych, Duchownych i Oświecenia Publicznego ${ }^{19}$ (The Government Commission for Internal, Spiritual Affairs, and Public Education - KRSWDiOP). He probably owed these lucrative positions not only to his competences but also (as can be presumed) to friendships and relationships among French and Polish officers - Bonapartists settled in the Kingdom of Poland ${ }^{20}$, members of the elitist former masonic lodge of the Grand National Orient of Poland ${ }^{21}$. Although this "royal art" (freemasonry)

Uniwersytetu Jagiellońskiego. Prace Historyczne” 2013, vol. 140, no. 1, p. 1.

14 S. Łoza, Rodziny polskie pochodzenia cudzoziemskiego osiadte $w$ Warszawie $i$ okolicach. [Vol.] 1, Warszawa 1932, pp. 9-10. pp. 5-6.

15 K. Dunin-Wąsowicz, Francuzi w Polsce. Podróże do kraju pod zaborami, Warszawa 2000,

16 A. Skałkowski, Bontemps Piotr (1777-1840), [in:] PSB. Vol. 2: Beyzym Jan - Brownsford Marja, Kraków 1936, pp. 305-306.

17 J. Łojek, Opinia publiczna a geneza Powstania Listopadowego, Warszawa 1982, pp. 229-234.

18 Edward August Landié, "Kurier Warszawski" 1853, no. 143, p. 729.

19 J. Schiller, Portret zbiorowy nauczycieli warszawskich publicznych szkót średnich 17951862, Warszawa 1998, p. 321.

20 T. Kurzawa, Rola oficerów-wolnomularzy w okresie Księstwa Warszawskiego, [online] https://repozytorium.amu.edu.p1/bitstream/10593/169/3/Rola\%20oficer\%C3\%B3w.\%20Kurzawa\%20Tomasz.pdf [retrieved on 06.01.2018].

21 N. Wójtowicz, Masoneria, Warszawa 2006, p. 9. 
was forbidden in the Kingdom of Poland by the Tsar Alexander 1st ukase of $1821^{22}$, French and Polish officers established their own intellectual, political and military elite in Warsaw. General P.K. Bontemps led the way among them ${ }^{23}$. A renowned, elite men school led by Landié since 1830 can be a prove of relationships among military and masonry generals of that time, graduated by sons of outstanding military officers. Count general Jan Krukowiecki ${ }^{24}$ wrote in a letter to his wife Helena née Wolska: "Concerns about Kajtuśs ${ }^{25}$ health, cold and cough are not fun for me, but after the letter from P. Landié I can assume that they will care for him also in his illness" ${ }^{26}$. Another school pupil was Włodzimierz Wolski, future author of opera librettos, including "Halka" and "Hrabina", composed by Stanisław Moniuszko, novels, poetry, perfect translations from French ${ }^{27}$. W. Wolski was the only son of Hipolit Wolski, major of the Duchy of Warsaw, adjutant of general Jan Krukowiecki. Konstanty Kamiński wrote about him: "He owned beginning of his education and throughout knowledge of French and German languages to I. Bertrand, as well as the schools of Landie [sic!] the Frenchman, and of Piltz the German"28.

The other hero of this article, S. Orgelbrand, was born in 1810 in the indigent Warsaw family of a Jewish trader Chaim Juda and Anna née Jud ${ }^{29}$. He gained an education in the Warsaw government School for Rabbis, which significantly supported the assimilation of the Jews ${ }^{30}$. Staying at school played an important role in shaping Orgelbrand's personality, developing his attachment to Jewish culture, combined with Polish patriotism ${ }^{31}$. Although he worked as a teacher in many rich Jewish families after graduation, finally he chose another profession. Bogdan Klukowski rightly emphasized: "His education was

22 S. Małachowski-Łempicki, Wykaz polskich lóż wolnomularskich oraz ich czlonków w latach 1738-1821 poprzedzony zarysem historii wolnomularstwa polskiego i ustroju Wielkiego Wschodu Narodowego Polskiego, Kraków 1929, p. 121. On this topic see also: L. Hass, Sekta farmazonii warszawskiej. Pierwsze stulecie wolnomularstwa w Warszawie (1721-1821), Warszawa 1980.

23 T. Kordala, Generat Wojska Polskiego Piotr Bontemps (1777-1840), polski ziemianin z Francji rodem, Płock 2017, pp. 4-6.

24 W. Zajewski, Jan Krukowiecki (1772-1850), [in:] PSB. Vol. 15: Kozłowska Zofia-Kubacki Stanisław, Wrocław 1970, pp. 392-397.

25 Konstanty Krukowiecki born in 1821 was the eldest son of the count J. Krukowiecki.

26 BUW, Gabinet Rękopisów, sign. 542, Korespondencja gen. Jana Krukowieckiego z żoną Heleną z Wolskich. Listy od 10.01.1832-11.11.1835.

${ }_{27}$ K. Kamiński, Materiały do życia i twórczości Włodzimierza Wolskiego, "Pamiętnik Literacki”, vol. 65 , no. 1,1974, p. 143.

28 Ibidem, p. 145.

29 W. Nussbaum, Szkice historyczne z życia Żydów w Warszawie od pierwszych śladów pobytu ich w tem mieście do chwili obecnej, Warszawa 1989, pp. 71-75.

30 Its pupils acquired knowledge of Hebrew, Polish, French in German during 4 years of education. The Old Testament, Midrash, Talmud, universal history of history of Poland, mathematics and geography were also taught there.

31 Ibidem. 
extraordinary among the Warsaw Jews of that time, therefore it is not surprising that this young man ambition directed towards the book and bookselling" ${ }^{32}$.

Career beginnings of either Landié or Orgelbrand were very difficult. First the November Uprising of 1830-1831, and after its failure, a time of "Paskiewicz night" ${ }^{33}$ did not support professional development. Russian repressions did not omit education, which can be explained by (among others) the youth participation in the uprising. The University of Warsaw was closed, Towarzystwo Warszawskie Przyjaciół Nauk (the Warsaw Society of Friends of Learning) was dissolved, and the education system reorganized ${ }^{34}$ by subordinating it to KRSWDiOP. Despite these changes, Warsaw still not lost its capital character and remained in the Poles' minds a center of national life. Liquidation of publishing houses and restrictions of freedom of printing led to increased demand, and in consequence to increase of prices of school textbooks and other Polish books. In this situation, S. Orgelbrand engaged in antiquarian trade in textbooks, which gave him a large profit. Besides, he was not the only Jew who became an antiquarian - "the Warsaw antiquarian trade in the $19^{\text {th }}$ century $[\ldots]$ was almost completely held by the Jews" ${ }^{\prime 35}$. The activity of that time was regulated by the KRSWDiOP instruction of September 10, $1834^{36}$. Two years later, in 1836, Orgelbrand opened his own antiquarian bookstore ${ }^{37}$.

Starting his publishing activity in 1836, Orgelbrand thought probably about publishing new textbooks, but his name is not listed among the Warsaw booksellers who gained a 10 years contract for printing primers for Okręg Naukowy Warszawski (Warsaw Education District, ONW) for the school year 1839-1840 in a public auction ${ }^{38}$. Therefore he started publishing popular French romances, which was profitable. Klaudia Kowalczyk writes "Gathering capital in this way, he expanded his company and moved to more ambitious activity"39, beginning independent publication of original Polish works. Stefan Lewandowski notices

\footnotetext{
32 B. Klukowski, Samuel Orgelbrand - księgarz, wydawca, drukarz. Dwusetna rocznica śmier$c i$, "Poradnik Bibliotekarza" 2010, no. 12, p. 3.

33 R. Gerber, Szkolnictwo Królestwa Polskiego w pierwszym dziesięcioleciu rządów Paskiewicza, "Rozprawy z Dziejów Oświaty" 1959, vol. 2, p. 167.

34 K. Poznański, Oświata i szkolnictwo w Królestwie Polskim 1831-1869. Lata zmagań i nadziei. Vol. 3: Polityka oświatowa caratu w latach 1834-1861, Warszawa 2004, pp. 74-77.

35 Dawne antykwariaty warszawskie, [eds. J. Jęśko, J. Myszkowska], Warszawa 2003, p. 62. See also: M.J. Lech, Księgarze i księgarnie w Królestwie Polskim 1869-1905. Materiały ze źródet archiwalnych, Warszawa 1980, p. 210.

36 S. Lewandowski, Powstanie przedsiębiorstwa Samuela Orgelbranda (1830-1868), "Rocznik Warszawski" 1971, vol. 10, pp. 116-117.

37 B. Golka, M. Kafel, Z. Kłos, Z dziejów drukarstwa polskiego, Warszawa 1957, p. 204.

38 J. Dobrzański, Szkolnictwo w Królestwie Polskim w roku szkolnym 1839, "Rocznik Lubelski" 1960, vol. 3, p. 258.

39 K. Kowalczyk, Księgarstwo warszawskie w drugiej połowie XIX wieku, Warszawa 2006, p. 212 .
} 
that searching for "attractive positions, Orgelbrand proposed cooperation to the outstanding scholars" ${ }^{40}$. He published approximately 500 works in Polish during his publishing, in almost 800 volumes. His offering consisted of (among others): editions of original Polish prose, dramas, literary studies, academic writings, either original concerning history of Poland, or translations from universal history, textbooks, and popular-science editions. Orgelbrand's publishing repertoire included 31 titles of coursebooks ${ }^{41}$. According to his contemporary Kraków bookseller Aleksander Nowolecki, Orgelbrand "tried to support such editions with more profitable publications - printing remunerative textbooks" ${ }^{\prime 2}$. Increasing editions, at the same time he decreased their prices ${ }^{43}$. While browsing his publishing catalogues, prospects, publishing supplements for the years 1840-1868, one could focus on a book description, including - besides author and title - also a translator, number of the following edition, pagination, maps, illustrations, and price. The books were organized according to a subject or alphabetically ${ }^{44}$. This proves the high professionalism of the publisher. He also took care of advertising his publications. Let's cite for example Katalog ksiażek polskich (The Catalogue of Polish books) (of the year 1852), offered in the S. Orgelbrand's bookstore:

Ktokolwiek w Królestwie lub Cesarstwie wybierze na raz książek Rub. sr. 15, otrzyma je franco, albo będzie miał rabat $10 \%$ Księgarnia ciągle sprowadza najnowsze dzieła zagraniczne. Katalog ten w miarę potrzeby dodatkami uzupełniać się będzie.

(Anyone in the Kingdom or Empire who will choose books for 15 silver rubles at one time, will receive them for free or with a $10 \%$ discount. The bookstore still imports the latest foreign works. The supplements to this catalogue will be added if necessary).

The company's activity was appreciated by the contemporaries. Franciszek Maksymilian Sobieszczański mentioned the great significance of the Orgelbrand publishing house in his description of Warsaw of the year 1848, "which is beyond any other with the volume of edition and selection of works" ${ }^{45}$. An anonymous author wrote in 1874, a few years after the publisher's death, in "Warszawski Rocznik Literacki" ("Warsaw Literary Yearbook"):

Istotny wydawca nie jest tylko pośrednikiem, pojmuje on każdo chwilowe żądania ogółu, umie odgadywać zaledwie rodzące się kierunki, sam wyszukuje piszących, pobudza ich, podaje pracę tam, gdzie ona sama przez się by się nie ujawniła. [...] Jeżeli jednak w każdym czasie ważnem jest znaczenie wydawcy księgarza, staje się ono o wiele donioślejszem, gdy

$40 \quad$ S. Lewandowski, op. cit., pp. 116-117.

${ }^{41}$ SPKP, ed. by I. Treichel, pp. 646-648.

42 A. Nowolecki, Samuel Orgelbrand, Kraków 1875, p. 21.

43 M. Mlekicka, Wydawcy ksiażek w Warszawie w okresie zaborów, Warszawa 1987, p. 70.

44 See S. Orgelbrand's publishing catalogues (1840-1868) in the collection of the Bibliological Reading Room, the National Library of Poland.

45 F.M. Sobieszczański, Rys historyczno-statystyczny wzrostu i stanu miasta Warszawy od najdawniejszych czasów aż do 1847 roku, Warszawa 1848, p. 446. 
piśmiennictwo narodowe znajduje się w zaczątkach lub zastoju, - gdy mało kto pisze, niewielu czyta, a nikt nic nie wydaje. [...] Na szczęście zastój ten nie trwał długo, a w rzędzie ludzi, którzy się najwięcej do ożywienia ruchu książkowego przyczynili, był bez zaprzeczenia Samuel Orgelbrand ${ }^{46}$.

(True publisher is not only a mediator, but he also understands each demand of the public, can guess trends to emerge, finds the writers himself, stimulates them, gives work where it would not appear by itself. [...] However, although the role of publisher and bookseller is important anytime, it becomes much more significant when national literature is at the beginning of stagnation, - when hardly anyone writes, a few reads, and no one publishes anything. [...] Fortunately, this stagnation has not taken long, and Samuel Orgelbrand was for sure among those who contributed most to the renewal of book movement).

When S. Orgelbrand had been developing his company, E. Landié still had been French literature and language lecturer. He taught in both Warsaw lower secondary schools for boys ${ }^{47}$. According to Adam Massalski, in the years 1842-1846, "he had been teaching in the $2^{\text {nd }}$ gymnasium in Warsaw, and in the gubernyal gymnasium there for the following year"48. Previously, in the years 1828-1848, he lectured in the Institute for Governesses and at Kursy Dodatkowe Pedagogiczne (Additional Pedagogical Courses), teaching level of which was perceived as the higher. Two years there was counted as one year of studies at the universities of the Russian Empire ${ }^{49}$. There is the following note in "Imienny spis urzędników i nauczycieli Okręgu Naukowego Warszawskiego za rok 1839-1840" (Personal list of officials and teachers of the Warsaw Education District for the year 1839-1840) at Landié name:

Francuz, wychowanek szkół paryskich, uczył języka francuskiego. Pochodził z rodziny szlacheckiej [sic!], liczył 54 lata. Za pracę na Kursach pobierał 2000 złp., a ponadto uczył w Instytucie Rządowym Wychowania Panien ${ }^{50}$.

(A French, graduate of Paris schools, taught French language. Originated from a noble [sic!] family, 54 years old. His remuneration for work at the Courses amounted to 2000 PLN, he also taught in the Government Institute of Women Education).

${ }_{46}$ Samuel Orgelbrand, [in:] Dziat III, Księgarstwo, "Warszawski Rocznik Literacki" 1874, vol. 4, pp. 2-3.

47 Renowned and deserved the Warsaw Lycee was active as the 1st Warsaw Gubernyal Gymnasium since 1833, and still was located in the Kazimierzowski Palace. Szkoła Wojewódzka Praktyczno-Pedagogiczna (the Regional Practical and Pedagogical School) at Leszno was renamed as Gymnasium in 1833, and again as 2nd Warsaw Government Gymansium in 1840, see J. Schiller, Nauczyciele szkót średnich Warszawy w pierwszej połowie XIX w.: szkic do portretu grupy zawodowej, Warszawa 1988, vol. 31, p. 84.

48 A. Massalski, Nauczyciele języka francuskiego męskich szkót średnich rządowych Królestwa Polskiego w latach 1833-1862, "Studia Pedagogiczne. Problemy Społeczne, Edukacyjne i Artystyczne" 1983 , no. 14 , p. 80.

49 K. Poznański, Kursy dodatkowe pedagogiczne w Warszawie 1836-1848, "Rozprawy z Dziejów Oświaty” 1978, vol. 21, pp. 20-22.

50 Cited after: Ibidem, p. 24. 
Photo 1. Katalog ksiązek znajdujacych się w księgarni S. Orgelbranda przy ulicy Miodowej Nr. 496..., Warszawa 1852. Source: BN, The Bibliological Reading Room. Photo by: Teresa Grabowska

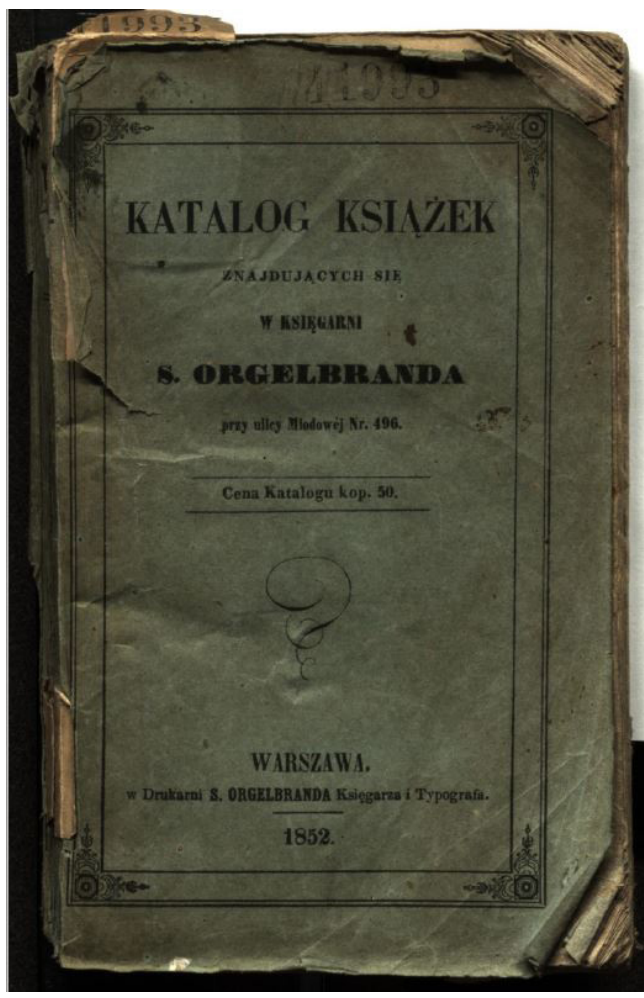

In 1840 he developed "Wypisy francuskie (French excerpts), which were to be obligatory in secondary schools of the Warsaw Education District, according to the Ministry of Education decision" 51 . He devoted his free time for working on pronunciation, French grammar, and French dictionaries for the Poles ${ }^{52}$.

Education in the Kingdom of Poland was substantially changed at the turnover of 1839-1840. Tsar signed his ukase on December 2, 1839, establishing

51 A. Massalski, Nauczyciele..., op. cit. See also K. Poznański, Kursy dodatkowe..., p. 24. On Landié's teaching work see also: Walka caratu ze szkoła polska w Królestwie Polskim w latach 1831-1870. Materiaty źródłowe, elaborated by K. Poznański, Warszawa 1994, pp. 77, 85, 319, 398; BUW, Gabinet Rękopisów, rps no. 2274, J. Lieder, Szkoła Wojewódzka. Gimnazjum 11 na Lesznie w Warszawie, p. 85.

52 J. Schiller, Portret zbiorowy..., op. cit. 
the main education authority in the Kingdom of Poland. That was the aforementioned Warsaw Education District, which officially was to support students of Polish schools in enrolling in studies at Russian higher schools. Actually, it functioned as the main education authority in the Kingdom of Poland ${ }^{53}$. Lower secondary schools and primary schools (district ones later) were supervised by ONW, subordinated to the Ministry of National Education in Saint Petersburg ${ }^{54}$. That meant a close relationship between education in the Kingdom of Poland and the Russian one. The educators were given carefully prepared instructions in 1840 or so, detailing the main rules of education and upbringing, as well as teaching methods and basic literature for 19 subjects $^{55}$. There was Instrukcja do wykładu języka francuskiego (Instruction for teaching French language) to "française" subject, in Russian and French languages: Instrukcija dla priepodawanija francuzskago jazyka w Gimnazijach = Programme de l'enseignement de la langue française dan s les Gymnases ${ }^{56}$. Basing on the rescript of February 17, 1843 $3^{57}$, Wykaz dziet wskazanych instrukcjami do wykładów przedmiotów $w$ gimnazjach $i$ szkolach powiatowych ${ }^{58}$ (The list of works named in the instructions to teaching subjects in lower secondary schools and district schools) was published. Among four titles indicated for teaching French language, two Landié's coursebooks were listed: "Grammaire française à l'usage des eleves des classes inferieures" and "Chrestomathie française en deuxparties" ${ }^{59}$, published by S. Orgelbrand.

Landié had been publishing his coursebooks for French language teaching in S. Orgelbrand's publishing house since $1840^{60}$. It is significant that the first volume of Chrestomathie française, ou choix de morceaux : de prose et de vers, suivie d'un vocabulaire of 1840 was dedicated just to the contemporary ONW superintendent, general lieutenant Mikołaj Okuniew ${ }^{61}$. Landié pursued favor of the Warsaw superintendent in this way. It was probably caused by the unstable professional situation of a teacher - immigrant from France. Complete loyalty to the Russian Empire was required in education, under the new school act of

53 K. Poznański, Oświata ..., op. cit.

54 M. Adrianek, Biblioteki publicznych szkół średnich Królestwa Polskiego w okresie międzypowstaniowym, "Folia Bibliologica" 2010, vol. 52, p. 32.

55 M. Adrianek, Ksiązki szkolne w Królestwie Polskim w latach 1843-1863, "Folia Bibliologica"1988/1989, vol. 36-37, p. 50.

56 S.l. (Warszawa?) s.a., cited after: Bibliografia Polska Estreicherów, [online] https://www. estreicher.uj.edu.pl/xixwieku/baza/wpis/?sort=nazwisko_imie\&order=1\&id=74129\&offset=0\&in$\mathrm{dex}=1$ [retrieved on 09.07.20019].

57 M. Adrianek, Książki..., pp. 51-52.

58 Ibidem, p. 67.

59 Ibidem, p. 71.

60 BN, sign. 83.751.

${ }_{61}$ More on M. Okuniew see e.g. J. Dobrzański, op. cit., p. 254. 
1833 concerning teachers' work. Educators who were not fully trusted by the government were dismissed. Rada Wychowania Publicznego (Council of Public Education) was responsible for the implementation of this regulation. Karol Poznański cites fragments of its correspondence with Sergiej Uwarow ${ }^{62}$, minister of public education, in his Kursy dodatkowe pedagogiczne $w$ Warszawie 1834-1848 (Additional pedagogical courses in Warsaw in 1834-1848):

Nie ma najmniejszej wątpliwości, [...] że szkodliwe nastawienie nadawane dzieciom, jeśli nie na zawsze, to na długie czasy w nich pozostanie. W Rosji przeciwdziałają temu nastawieniu sami rodzice; sami rodzice uczą swoje dzieci oddania i miłości dla Ojca - Pana. Ale tu, tu jest rzeczą niezbędną przeciwdziałanie, gdyż przybyły ze Szwecji, Francji, czy z Niemiec guwerner nie nauczy tutejszego rodaka kochać Rosję. Czyż ci ludzie, którym na nieszczęście bez zastanowienia powierza się tu wychowanie dzieci, obznajmieni są chociaż trochę z potęgą i chwałą Rosji? Te okoliczności w połączeniu z wprowadzonym teraz w wykonanie zarządzeniem o prywatnych zakładach naukowych i domowych nauczycielach szczególnie zajmują Radę Wychowania Publicznego. W miarę swoich możliwości stara się usuwać i wykorzeniać zło, dążąc krok po kroku do zlikwidowania wszystkiego, co szkodliwe i co przynoszone jest z zagranicy ${ }^{63}$.

(Harmful attitude shaped in children will remain in there for a long time, if not forever, there is no doubt. [...] The parents themselves counteract that attitude in Russian; they teach their children loyalty and love to the Father - the Master. However, here counteraction is indispensable, as a tutor from Sweden, France or Germany will not teach a countryman love Russia. Are those people, who, unfortunately, without thinking, are entrusted with raising children here, familiar with at least a little with the power and glory of Russia? These circumstances, together with just implemented regulation on private education institutions and home tutors, are of particular interest to the Council of Public Education. If possible, it strives to remove and eradicate evil, striving step by step to eliminate everything that is harmful and brought from abroad).

Mikołaj Okuniew, a superintendent, declared work in this field as his great and holy duty towards the Russian Empire.

E. Landié, thanks to his pedagogical and creative work, became the Warsaw French language teacher and became one of the best educators.

It is worth noting that the second volume of Chrestomathie française [...] accompagnée de notes explicatives et d'ue notice biographiquez of 1841, available in the National Library of Poland collection, includes Landié's autograph and a personal stamp of Orgelbrand (Photo 3).

Publishing E. Landié's coursebooks by S. Orgelbrand enhanced positions of both its author and publisher in the Warsaw school books market and within

62 C.H. Whitteaker, The Orginis of Modern Russian Education: an Intellectual Bipgraphy of Mount Sergei Uwarow, Illionois 1984. [review] K. Bartnicka, "Rozprawy z Dziejów Oświaty" 1993. vol. 33, pp. 245-248.

63 K. Poznański, Kursy dodatkowe ..., op. cit., p. 37. 
the Kingdom of Poland. They both benefited from it personally, but the Polish society, its education, and culture did it as well. There was also an indirect social benefit, as due to profits from the sale of re-published textbooks Orgelbrand could self-publish e.g. valuable literary or scientific works ${ }^{64}$, thereby shaping the reading preferences of the Poles. Kazimierz Władysław Wóycicki described this process as follows:

W ruchu i rozwoju literackiego życia, niepoślednią rolę grają księgarze nakładcy. Zawód ich, z jedynym a widocznym celem osobistego zysku, w ostatecznym wyniku, przynosi obfite dla ogółu korzyści. Sądzimy, że nikt nie dopuści porównania co do zasług, jakie niektórzy chcą robić pomiędzy takim nakładcą a literatem z powołania. Przepaść ich dzieli, chociaż nieraz interes ściśle łączy ${ }^{65}$.

(Booksellers and publishers play a prominent role in the development of a literary life. Their profession, although aimed at personal profit, finally brings large benefits for the public. We believe that no one would permit a comparison of the merits that some want to do, between such a publisher and a writer by vocation. The gap divides them, although sometimes a business strongly connects.)

Further, he concluded:

Cóż jest wydawca, podejmujący swoim kosztem nakłady? [...] Jak doświadczony lekarz, po uderzeniach pulsu, bada stan chorego, tak nakładca, musi badać tętna duchowe społeczności. Jeżeli do wykształcenia, łączy energię przedsiębiorczą, a dobrze już zbadał pragnienia publiczności, nietylko [sic!] że dogadza ochotnie jej zachciankom chwilowym, ale przewidując prąd ich nowy, lub możność skierowania na nowe drogi, sam je wskazuje i dobiera odpowiednich pracowników. W tem też leży różnica, pomiędzy prostym handlarzem książek, a rozumnym nakładcą, który położyć może niezapomniane zasługi dla literatury krajowej, pomimo ciągłej dążności do zarobku korzystnego ${ }^{66}$.

(Who is a publisher, who undertakes to publish at own cost? [...] As an experienced doctor after pulse beats examines patient's condition, a publisher has to examine spiritual pulse of the society. If he joins entrepreneurial energy with education, and well-examined public desires, not only he willingly answers its momentary fancies but forecasting their new trends or potentiality of new directions, he indicates them personally and selects appropriate employees. This is also a difference between a simple bookseller and a mindful publisher, who can place unforgettable merits for national literature, despite the constant desire for satisfactory profit).

E. Landié had been involved with this first-class publishing house until the end of his life. His coursebooks for French language teaching were so good and popular that they had several editions during the author's life, which was not often seen in that time. Landié retired in 1848, however, he continued his

${ }^{64}$ On this topic see also: M. Kuna, Drukarnia, ksieggarnia i wydawnictwa Samuela Orgelbranda (1810-1868), "Przegląd Biblioteczny" 1955, no. 3-4, p. 312.

65 K.W. Wóycicki, Samuel Orgelbrand, "Kłosy” 1868, no. 179, p. 295.

66 Ibidem, p. 296. 
work, although in a limited scope. He died on June 6,1853, as was buried in the Powązki cemetery ${ }^{67}$.

S. Orgelbrand continued to publish his coursebooks after his death. When the company was taken over by his sons in $1871^{68}$ (after Samuel's death in 1868), the Russian and French version of Grammatyka francuzka was published, titled Grammaire française à l'usage des commençans... = Francuzskaâ grammatika dlâ načinaûsihičcit'sâ semu âzyku .. ${ }^{69}$ Leoncjusz Landié, Edward's son, could have been the author of this translation. He worked as an official in Russian public institutions in Warsaw and was the author of Zbior rozmów francuzko-polskich z dodaniem sprostowania przeszło 200 błędnych sposobów mówienia Polakom właściwych = Recueil des dialogues français-polonais, suivi d'un corrigé de plus de 200 locutions vicieuses, particulieres aux Polonais (three editions in Warsaw, 1842-1845). Following three editions of Grammaty$k a$ francuzka were published by the S. Orgelbrand and Sons company in the following years (the ninth in $1876^{70}$, the tenth in $1882^{71}$, and the eleventh in $1897^{72}$ ). As wrote in Stownik pracowników ksiażki polskiej (Dictionary of the Polish Book Workers), after S. Orgelbrand's death "many earlier titles were re-published, including E. Landie's [sic!] Gramatyka francuska dla poczatkujacych $(1876,1882,1897)$ "'73.

The Russian language was privileged in that time, and teaching the German language was more appreciated in so-called real schools, i.e. focused on trade, farming or technology. Teaching French apparently faded. However, it still was the first foreign language of Polish intellectual elites, the language of either the official or the secret politics.

${ }^{67}$ Edward August Landié, "Kurier Warszawski" 1853, no. 143, p. 729.

68 On the S. Orgelbrand's company after his death, see e.g. M. Horoszewicz, Orgelbrandiana w zbiorach Muzeum Drukarstwa Warszawskiego, "Almanach Muzealny” 2014, vol. 8, pp. 299-303.

${ }^{69}$ BUW, sign. 17.18.6.61.

70 SPKP, p. 645.

71 E. Landié, Grammatyka francuzka dla początkujacych, BN, sign. 88.836.

72 Idem, Grammatyka francuzka dla początkujacych, BUW, sign. 4g.22.2.537. See also Katalog Księgarni Nakładowej Towarzystwa Akcyjnego S. Orgelbranda Synów w Warszawie..., Warszawa 1902 , p. 7.

73 SPKP, op. cit. 
Photo 2. E. Landié, Chrestomathie française... Vol.1, Warszawa 1840.

Source: BN, sign. 83.751 vol. 1. Photo by: Teresa Grabowska

\section{CIIRESTOHATHIE}

FRANÇAISE,

OL' CHOIX DE MORCEAUX DE PROSE ET DE VERS, SUIVIE D'UN vocabutatBE.

OUVBagR PERMIS PAR LE CONSEIL DE L'ISSTBUCTION PUBLQUE

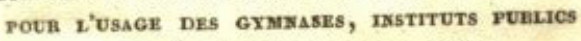

ET PRIVÉS DU hOYAUNE DE POLOGNE.

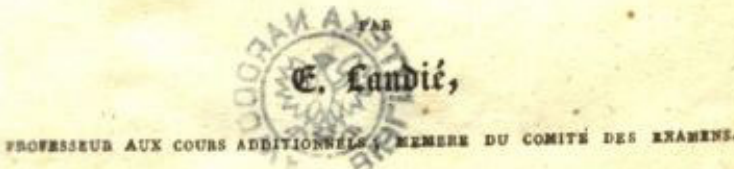

TOME $\mathbf{L}$

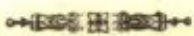

\section{VARSOVIE,}

CHzz ORGELBRAND LmaARI ,

Rue du Miel $n^{0}: 496$.

18,40 .

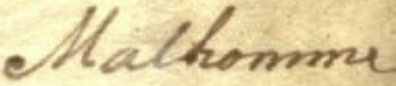


Photo 3. E. Landié, Chrestomathie française... Vol. 2, Warszawa 1841. Source: BN, sign. 83.751 vol. 2. Photo by: Teresa Grabowska

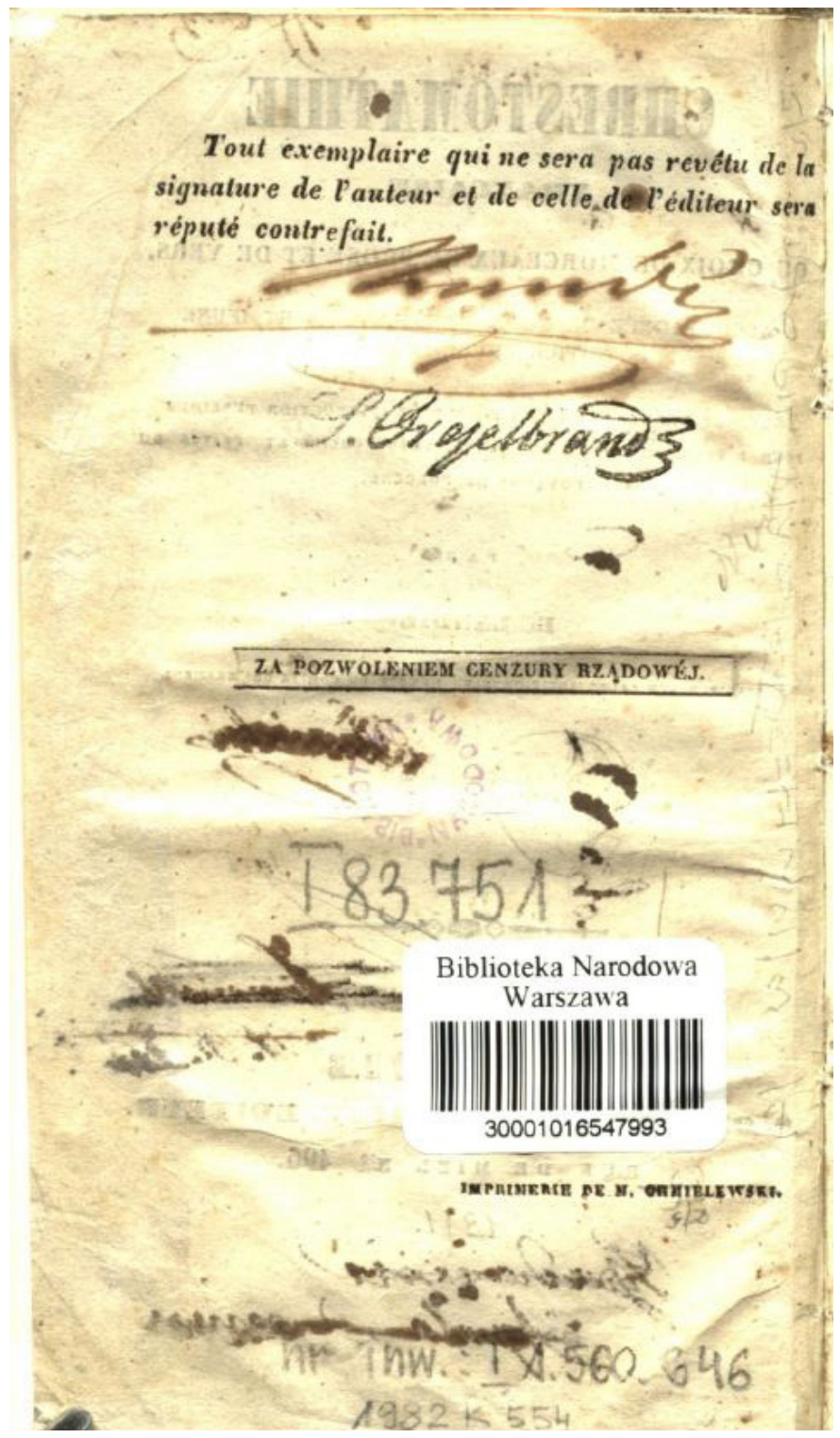


Photo 4. Foreword to the $10^{\text {th }}$ edition of Grammatyka francuzka..., Warszawa 1882.

Source: BUW, sign. 5.7.10.127. Photo by: Teresa Grabowska

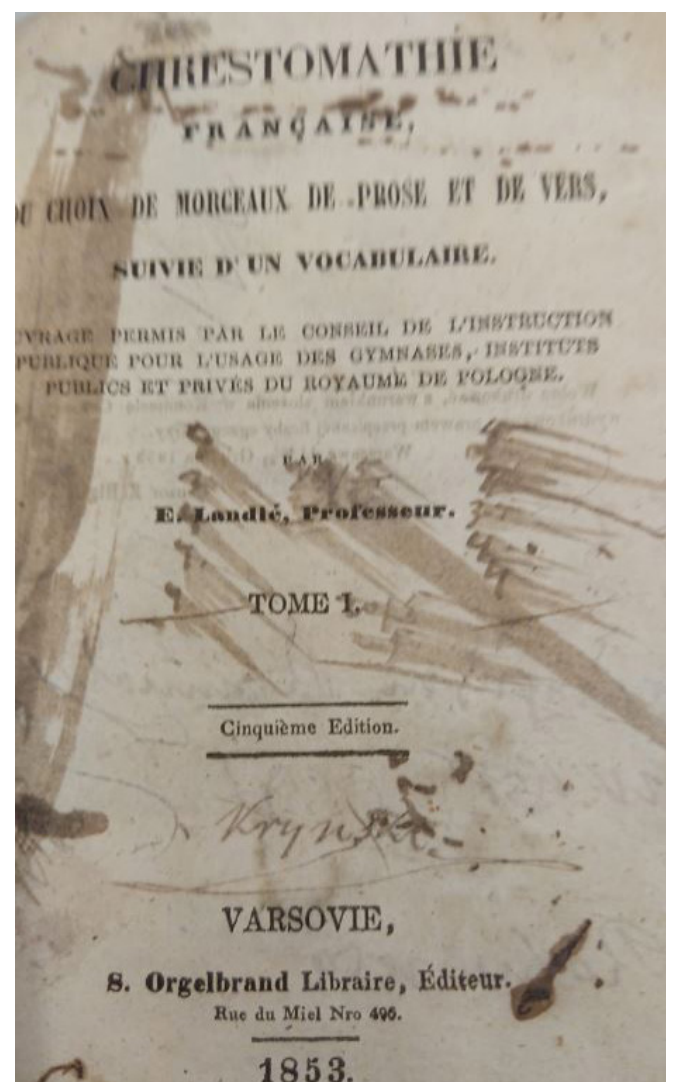

Six teachers of the French language, from among 45 employed in the Kingdom of Poland, had been writing coursebooks in the time between uprisings. The authors of French excerpts made 13\% of French teachers. Except for the hero of this article, the other authors are presented in chronological order below:

- Józef Zieliński (1785-1857) taught French language in the Gubernyal Gymnasium in Warsaw in the years 1834-1838. His textbooks reached previous years, however, they were published also after the November Uprising. He was the author of Gramatyka francuska teoretyczno-praktyczna ułożona dla Polaków (Part 1, 1816, Part 2, 1818). The last, fi$\mathrm{fth}$ edition was published in 1835 and was included in the textbooks' register. He also published Rozmowy potoczne stużace do gramatyki francuskiej in $1816,2^{\text {nd }}$ edition in 1826 , and $3^{\text {rd }}$ edition in 1836 . He wrote Cours de litterature française, (3 volumes in 1823). Only the third 
volume was placed in the textbooks' register to be used in the schools of the Kingdom of Poland ${ }^{74}$.

- Wiktoryn Zieliński (1810-1866), graduate of the gymnasium in Niemirów, governorate of Podole, the Russian Empire. He started his work as a private teacher of the French language in Kielce and Częstochowa. He taught Polish language, geometry, and geography in the Real District School in Warsaw in the years 1859-1862. He was the author of the textbook Nowy komeniusz czyli pierwiastki konwersacji polskiej, francuskiej i niemieckiej obejmujący: 1) zbiór wyrazów $i$ wyrażeń najużywańszych $w$ stosunkach towarzyskich, 2) wzory potocznej konwersacji, 3) gramatyczne początki trzech wymienionych języków, which had 7 editions $\left(1838,2^{\text {nd }}\right.$ edition $1841,3^{\text {rd }}$ edition 1847 , $4^{\text {th }}$ edition $1853,5^{\text {th }}$ edition $1858,6^{\text {th }}$ edition $1869,8^{\text {th }}$ revised edition 1889). He also published two editions of Przewodnik - do konwersacji czyli praktycznej nauki języka francuskiego (1866), $2^{\text {nd }}$ revised edition titled Przewodnik rozmów francuskich (1869) ${ }^{75}$.

- Wiktor Denoix (1811-1869), graduate of the Royal Lyceum in Bordeaux. He taught in the Gymnasium in Lublin (1839-1840), in the II Gymnasium in Warsaw and the District School in Warsaw (1849-1850). He was a superintendent of Warsaw private schools since 1860. He published Zbiór wyrazów francuskich najużywańszych, celem ułatwienia trudności zachodzacych w tym języku (1844, $2^{\text {nd }}$ edition 1859). In 1855 he published French excerpts Nouvelle chrestomathie française ou recueil de morceaux choisis des meilleurs ecrivains français, gradues et mis en ordre. The excerpts were not accepted for school usage, with no reason given by the Examination Committee. However, they were published in the following years $\left(2^{\text {nd }}\right.$ edition $1858,3^{\text {rd }}$ edition $1859,4^{\text {th }}$ revised edition 1860$)$, which might mean that the Examination Committee finally accepted them. W. Denoix published the textbook Nowe rozmowy francuskie (1858, $2^{\text {nd }}$ edition 1860), and the excerpts Gramatyka francuska (po polsku i francusku) and Cours de litterature française in $1860^{76}$.

- Adolf Krzewski (1815-1862), graduate of the School of Industry and Trade in Charon, France. He was a teacher of the French language in the gymnasium in Płock (1853-1860), and afterward in the Noble Institute (1861-1862) and at the Preparatory Courses to the Main School (1862). He published one French grammar for gymnasia in the Kingdom of Poland, Gramatyka francuska teoretyczna i praktyczna dla użtku młodzieży

74 E. Kula, Naukowa, literacka i artystyczna twórczość nauczycieli rządowych męskich szkót średnich Królestwa Polskiego w latach 1833-1862, Kielce 2006,, p. 153.

75 Ibidem, pp. 150-151.

76 Ibidem, p. 152. 
polskiej $=$ Recueil gradue de lectures et d'exercies dememoire en prose et en vers, à l'usage de la jeunesse polonaise (vol. 1 1863, vol. 2 1864) ${ }^{77}$.

- Aleksander Matuszewski (1822-1874), graduate of the Gubernyal Gymnasium in Warsaw. In the years 1854-1861 he taught the French language in the District School in Pińczów. He published Rys systematyczny gramatyki francuskiej in 1843, Wyktad praktyczny języka francuskiego, czyli najłatwiejszy sposób szybkiego nauczenia się mówić po francusku in 1849, and Znaczenie wyrazów zawartych w III i IV części wyktadu praktycznego języka francuskiego in 1849. In 1854 he wrote the textbook Nauka czytania francuskiego, which was not accepted by the Examination Committee, as not fulfilling requirements to be applied in the schools of the Warsaw Education District for teaching the French language ${ }^{78}$.

After analysis of the output of the aforementioned authors of coursebooks for French language teaching, E. Landié was considered as a prominent one among them. His output concerning teaching modern language in the publishing market of the Kingdom of Poland was outstanding and ground-breaking. Landié's coursebooks became a mark and was published after the author's death in the following 44 years, until 1897. As a teacher of public secondary schools, Landié popularised science through the modernization of teaching methods. He developed his own methodical tools, i.e. coursebooks for pupils at different levels of education. He offered innovative, pioneer methods of teaching French as a modern language in these books. Basing on his long pedagogical experience, he developed a workshop of French language teaching methods for himself, as well as for the others. Material values are the other important aspect. Teachers of modern languages were paid less than other educators. $\mathrm{He}$ was unable to sustain his family basing only on remuneration, therefore he run a private school for boys, provided private lessons of the French language, and wrote coursebooks. It served the common good.

Undoubtedly, he reached his goal presented in the foreword to the $10^{\text {th }}$ edition of Grammatyka francuzka...: "This book [Chrestomathie...], together with current Grammatyka, will extremely support refinement of teaching [French language], I believe". These positions became obligatory aids in teaching French language in public schools of the Kingdom of Poland. Undoubtedly, besides official recommendation, their publisher S. Orgelbrand contributed to the success, taking care of their high editorial quality. Therefore this is also thanks to their cooperation - the author and the editor - school books discussed in this article became a reference for methods of teaching modern language in publishing houses offering textbooks.

Ibidem.

78 Ibidem, p. 153. 
Photo 5. Preface to the $10^{\text {th }}$ edition of Grammatyka francuzka..., Warszawa 1882. Source: BUW, sign. 5.7.10.127. Photo by Teresa Grabowska

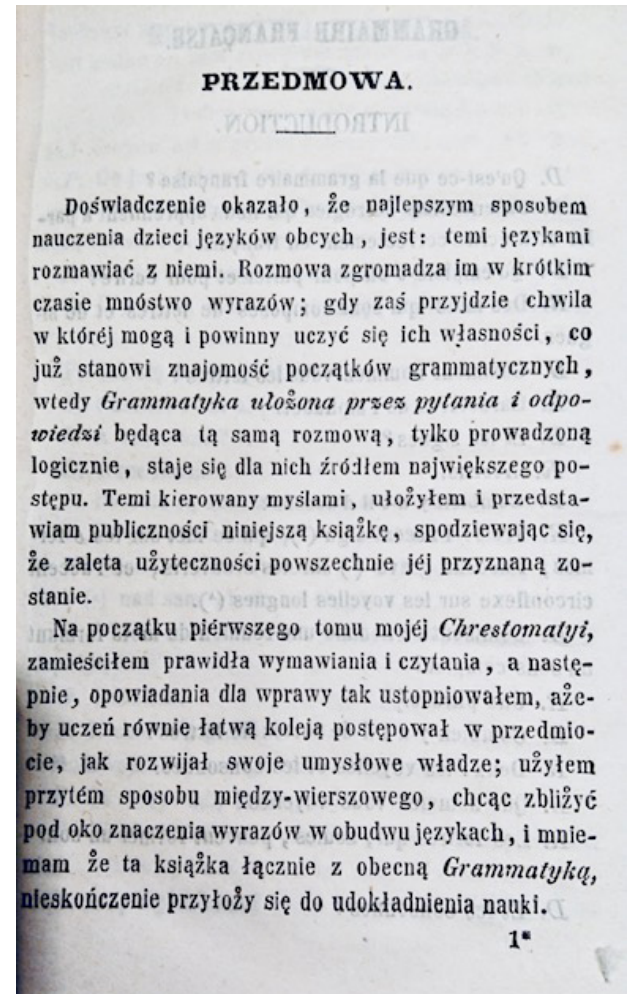

Analysis of the author's output, based on manuscript and printed sources as well as the literature, offers a wide and interesting picture of his creative activity. Diminishing of Landié's role, and his presentation only on the background of the professional and creative group was mentioned. The article is the first which presents E. Landié's output previously omitted in research.

E. Landié's coursebooks published by S. Orgelbrand's company in the years 1840-1897 in bibliographies and library collections of the National Library in Warsaw (BN) and the University of Warsaw Library (BUW)

Publications listed in S. Orgelbrand's company publishing catalogues, in chronological order, in the collections of the National Library and the University of Warsaw Library, also registered in the $2^{\text {nd }}$ volume of Bibliografia polska XIX. Stulecia by Karol Estreicher ${ }^{79}$. Titles of the positions cited in the aforementioned sources receive detailed description, based on preserved copies, in footnotes. Positions not found in the aforementioned library collections are marked with (*).

79 K. Estreicher, Bibliografia polska XIX. stólecia. Vol. 2: (G-L), Kraków 1874, p. 547. 
1840

"Chrestomathie française..."

"Grammatyka francuzka dla poczynajacych..."

\section{1}

"Chrestomathie française ou choix de morceaux de prose et de vers, suivie d'un vocabulaire [...] tom. II, 1841. (Wyczerp.) 75 [kopiejek]"

Chrestomathie française... T.183;

"Grammatyka Francuzka dla poczynających w francuzkim i polskim języku [...] Edycya2ga Warszawa 1841 [...] 2 [złp]"84;

\section{5}

* "Chrestomathie française... Wyd. 3" 85 ;

"Grammatyka francuzka dla poczynających, z textem francuzkim i polskim, wydanie 3cie, 12, Warszawa 184. zł. 2" "86;

* "Grammatyka Francuzka dla poczynających [...] z textem francuzkim i polskim (wydanie drugie) [sic!] 1845 [...] 2 [zł]" ${ }^{\prime 87}$;

$80 \quad$ Title cited after BN sign. 83.751 vol. 1 - E. Landié, Chrestomathie française, ou choix de morceaux de prose et de vers, suivie d'un vocabulaire. Vol. 1, Varsovie: S. Orgelbrand, 1840, [6], 206, [2], 76, [1] page: erratum; $18 \mathrm{~cm}$. In the publishing address of the BUW copy: Varsovie: Imprimerie de la Banque de Pologne, 1840. K. Estreicher, op. cit.: “ [...] II. Vol. Varsovie, imprim. de I. Dietrich, S. Orgelbrand; Tom I. r. 1840, w 8ce, str. 206 i 76, niel. 1.3 złp. 15 gr.”.

81 Title cited after BUW sign. 4.29.6.5. - E. Landié, Grammatyka francuzka dla poczynajacych..., Warszawa: w Drukarni Banku Polskiego, 1840, 96 s. ; 20 cm; K. Estreicher, op. cit.: "2 złp.".

82 Katalog dziet nakładowych Księgarni S. Orgelbranda. Sierpień 1858, Warszawa 1858, s. 21; BUW sign. 4.29.6.31. [1-2 współoprawne] - E. Landié, Chrestomathie française, ou choix de morceaux de prose et de vers, suivie d'un vocabulaire. T. 2, Varsovie: S. Orgelbrand Libraire, Editeur, 1841, [2], 76 s. ; 18 cm. K. Estreicher, op. cit.: "[...] Tom II. Warszawa, 1841, w 8ce, str. 396 i niel. 2.5 złp.”.

83 Cited after BUW sign. 4.29.6.31. [1-2 współoprawne] - T. 1. Seconde edition, [4], 206 s.; K. Estreicher, op. cit.: "[...] wydanie drugie [...] 1841, w 8ce, str. 206 i 76".

${ }^{84}$ Wyciag z katalogu ksiag polskich znajdujących się w Księgarni S. Orgelbranda, Warszawa 1846, s. 7; BUW, sign. 4.28.5.7. - E. Landié, Grammatyka francuzka dla poczynajacych... Druga edycya przejrzana i poprawiona. Warszawa: nakładem S. Orgelbranda Księgarza, 1841, 102 s.; 20 cm. K. Estreicher, op. cit.: "2 złp.".

85 Third edition of Chrestomathie française... registered by K. Estreicher, op. cit.: "Toż. Wydanie trzecie. Tomów II. Ibidem, 1845". No copy available in analysed library collections.

86 Katalog książek znajdujacych się w księgarni S. Orgelbranda przy ulicy Miodowej Nr. 496..., Warszawa 1852, s. 157; BN sign. 1.216.761A - E. Landié, Grammatyka francuzka dla poczynajacych $\ldots=$ Grammaire française a l'usage des commençans... Wydanie trzecie przejrzane i poprawione, Warszawa: nakładem i drukiem S. Orgelbranda, 1845, $102 \mathrm{~s}$. ; $18 \mathrm{~cm}$. K. Estreicher, op. cit.: "2 złp.".

87 Katalog dziet nakładowych Ksiegarni S. Orgelbranda. Luty 1847, Warszawa 1847, s. 5. No copy available of the $2^{\text {nd }}$ edition of 845 in analysed library collections. K. Estreicher does not register this edition, see op. cit. 


\section{6}

* "Chrestomathie française ou choix de Morceaux de prose et de vers, suivie d'un vocabulaire [...] (4 édition). [...] tom I. 1846. [...] 75 [kopiejek]"88;

\section{8}

"Chrestomathie française ou choix de morceaux de prose et de vers, suivie d'un vocabulaire [...] 4 edition, 12. tom 1szy, Warszawa 1848 zł 3 [...] tom 2gi, Warszawa 1841. zł 5"89;

"Grammatyka francuzka, dla poczynających. Wydanie czwarte, przejrzane i poprawione, $1850[\ldots] 30$ [kopiejek]"

\section{3}

"Chrestomathie française ou choix de morceaux de prose et de vers, suivie d'un vocabulaire [...] (5 edition) tom I. 1853 [...] 52 [rubli] 1/2 [kopiejek]" ${ }^{p 1}$;

\section{4}

"Grammatyka francuzka, dla początkujących, wydanie piąte, przejrzane i poprawione, $1854[\ldots] 30$ [kopiejek]"92

\section{5}

* "Chrestomathie française... Wyd. 6" "93;

88 Katalog dziet naktadowych Księgarni S. Orgelbranda. Kwiecień 1852, [Warszawa 1852], s. 13; K. Estreicher does not register the edition of Chrestomathie française... of 1846, op. cit. No copy available in the analysed library collections.

89 Katalog ksiażek znajdujacych się w księgarni S. Orgelbranda przy ulicy Miodowej Nr. $496 \ldots$. Warszawa 1852, s. 157; fourth edition of Chrestomathie française ... registered by K. Estreicher, op. cit.: "Toż. Czwarta edycya, 1848". No copy available in the analysed library collections.

90 Katalog dziet naktadowych Ksiegarni S. Orgelbranda. Marzec 1854, [Warszawa 1854], s. 19; fourth edition of Grammatyka... registered by K. Estreicher, op. cit.: "Toż, wydanie czwarte, przejrzane i poprawione. - Grammaire française à l' usage des commençans. $4^{\mathrm{me}}$ édition, Varsovie, Orgelbrand, 1850, w 12ce, str. 107. 2 złp.”. No copy available in the analysed library collections.

91 Katalog dziet nakładowych Księgarni S. Orgelbranda. Marzec 1854, [Warszawa 1854], s. 19; BN, sign. 455.802 - E. Landié, Chrestomathie française, ou choix de morceaux de prose et de vers suivie d'un vocabulaire... [T.] 1. Cinquieme edition, Varsovie: S. Orgelbrand, 1853, 175, [1] s. ; $18 \mathrm{~cm}+$ Słowniczek : 65 s.; BUW, sign., 5.5.6.54. [1] - T. 1. Cinquième edition, Varsovie: S. Orgelbrand Libraire Editeur, 1853, 175, [1], 65 s. ; 20 cm. K. Estreicher, op. cit.: "piąta edycya [...] w 8ce, str. 177 i $65.52 \frac{1}{2}$ kop.".

92 Katalog dziet nakładowych [...] Sierpień 1858, op. cit. Fifth edition of Grammatyka ... registered by K. Estreicher, op. cit.: "wydanie piąte. Warszawa, 1854, w 12ce". No copy available in the analysed library collections.

93 Sixth edition of Chrestomathie française... registered by K. Estreicher, op. cit.: "Toż. 6me édition. Varsovie, Orgelbrand, 1855, w 8ce, str. 177 i 65 ". No copy available in the analysed library collections. 
1858

"Grammatyka francuska dla początkujących. Wydanie szóste. Warszawa, 1858, kop.30"94;

\section{4}

"Grammatyka francuzka, dla początkujących, wydanie siódme, przejrzane i poprawione, 1864 [...] 30 [kopiejek]"95;

1869:

Grammatyka francuzka dla poczatkujacych... = Grammaire française... Wyd. $8^{96}$;

\section{1}

"Grammaire française... = Francuzskaâ grammatika dlâ načinaûsihučit'sâ sетu âzyku...97;

1876

"Grammatyka francuzka dla początkujacych ... = Grammaire française... Wyd. 9." 98

1882

"Grammatyka francuzka dla początkujacych $\ldots$ = Grammaire française... Wyd. 10"99;

94 Dodatek 9-ty do katalogu dziet znajdujących się w Księgarni S. Orgelbranda, [Warszawa 1859], p. 7; BN, sign. 1.515.981 - E. Landié, Gramatyka francuzka dla początkujących ... = Grammaire française a l'usage des commençans... Sixième édition, Varsovie: S. Orgelbrand Libraire Editeur, 1858, 132, [1] s. ; 21 cm; BUW, sign. 5.13.6.11. - Gramatyka francuzka dla poczatkujacych... Wydanie szóste, Warszawa: nakładem i drukiem S. Orgelbranda, 1858, 132, [1] s. ; 21 cm. K. Estreicher does not register this edition, see op. cit.

95 Katalog dzieł nakładowych Księgarni S. Orgelbranda. Maj 1867, Warszawa [1867], s. 12; BN, sign. 2.007.346 A; BUW, sign. 107450 - E. Landié, Grammatyka francuzka dla poczatkujacych ... = Grammaire française a l'usage des commençans... Wydanie siódme, Warszawa: nakładem i drukiem S. Orgelbranda, 1864, 147, [1] s. ; $18 \mathrm{~cm}$. K. Estreicher, op. cit.: registers title and publihsing address in French language, as well as a format "w 8ce".

96 Cit. after BN, sign. 54.964 i BUW, sign. 4.8.8.5. - Grammatyka francuzka dla początkujacych $\ldots=$ Grammaire française a l'usage des commençans... Wydanie ósme, Warszawa: nakładem i drukiem S. Orgelbranda, 1869, 147, [1] s. ; 280 cm. K. Estreicher does not register this edition, see op. cit.

97 Cit. after BUW, sign.17.18.6.61. - E. Landié, Grammaire française a l'usage des commençans ... = Francuzskâ̂ grammatika ..., Varsovie: chez S. Orgelbrand, Libraire Editeur, 1871, 158, [1] s. ; $18 \mathrm{~cm}$. K. Estreicher does not register this edition, see op. cit.

98 Cit. after BN, sign. 898.150 A, BUW, sign. 17.15.6.34. - Grammatyka Francuzka dla początkujących ... = Grammaire française a l'usage des commençans... Wydanie dziewiąte, Warszawa: nakładem i drukiem S. Orgelbranda Synów, 1876,143, [1] strona ; 21 cm. K. Estreicher does not register this edition, see op. cit.

99 Cit. after BN, sign. 88.836; BUW, sign. 5.7.10.127.- Grammatyka francuzka dla początku- 


\section{7}

"Grammaire française a l'usage des commençans, 11-e wydanie. 1897 30 kop.]"100.

Translated by Matgorzata Kisilowska

\section{References}

Archive sources

BUW, Gabinet Rękopisów, rps no. 542, Korespondencja gen. Jana Krukowieckiego z żoną Heleną z Wolskich. Listy od 10.01.1832-11.11.1835.

BUW, Gabinet Rękopisów, rps no. 2274, J. Lieder, Szkoła Wojewódzka. Gimnazjum 11 na Lesznie w Warszawie.

Municipal Archives et Agen, sygn.3Q1/10/1, Collection of parchment documents.

Print sources

Brunet J.- C., Manuel dulibraire et de l'amateur de livres... [Vol. 5], Bruxelles 1845.

Dodatek 9-ty do katalogu dziet znajdujacych się w Księgarni S. Orgelbranda, [Warszawa 1859].

Edward August Landié, "Kurier Warszawski” 1853, no. 164, pp. 825-826.

Edward August Landié, "Kurier Warszawski”" 1853, no. 143, p. 729.

Estreicher K., Bibliografia polska XIX. stólecia. Vol.2: (G-L), Kraków 1874.

Ignacy Bertrand, "Kurier Warszawski” 1861, no. 282, p. 1438.

Katalog dzieł nakładowych Księgarni S. Orgelbranda. Kwiecień 1852, [Warszawa 1852].

Katalog dzieł nakładowych Księgarni S. Orgelbranda. Luty 1847, Warszawa 1847.

Katalog dziet nakładowych Księgarni S. Orgelbranda. Maj 1867,Warszawa [1867].

Katalog dziet nakładowych Księarni S. Orgelbranda. Marzec 1854, [Warszawa 1854].

Katalog dziet nakładowych Księgarni S. Orgelbranda. Sierpień 1858, Warszawa 1858.

Katalog książek polskich znajdujących się w Księgarni S. Orgelbranda przy ulicy Miodowej Nr.

496 zawierający też książki teologiczne, słowniki, grammatyki i atlasy jeograficzne w różnych językach wraz z dwoma dodatkami i katalogami dziet nakładowych..., Warszawa 1852.

jacych...$=$ Grammaire française a l'usage des commençans... Wydanie dziesiąte, Warszawa: nakładem i drukiem S. Orgelbranda Synów, 1882, 143, [1] s. ; 19 cm. K. Estreicher does not register this edition, see op. cit.

100 Katalog Księgarni Nakładowej Towarzystwa Akcyjnego S. Orgelbranda Synów w Warszawie ul. Zgoda No 7, Warszawa [1902], s. 7; BUW, sign. 4g.22.2.537. - Grammatyka Francuzka dla poczattujacych ... = Grammaire française à l'usage des commençans... Wydanie jedenaste, Warszawa: nakładem i drukiem S. Orgelbranda Synów, 1897, 143, [1] s. ; 20 cm. See also K. Estreicher does not register this edition, see. op. cit. 
Katalog Księgarni Nakładowej Towarzystwa Akcyjnego S. Orgelbranda Synów w Warszawie..., Warszawa [1902].

Katalog książek znajdujących się w księgarni S. Orgelbranda przy ulicy Miodowej Nr. $496 \ldots$, Warszawa 1852.

Samuel Orgelbrand, [w:] Dziat III, Księgarstwo, "Warszawski Rocznik Literacki" 1874, vol. 4, pp. 1-6.

Nowolecki A., Samuel Orgelbrand, Kraków 1875.

Nussbaum W., Szkice historyczne z życia Żydów w Warszawie od pierwszych śladów pobytu ich w tem mieście do chwili obecnej, Warszawa 1989.

Sobieszczański F.M., Rys historyczno-statystyczny wzrostu i stanu miasta Warszawy od najdawniejszych czasów aż do 1847 roku, Warszawa 1848.

Wóycicki K.W., Samuel Orgelbrand, “Kłosy” 1868, no. 179, pp. 295-296.

Wyciag z katalogu ksiag polskich znajdujących się w Księgarni S. Orgelbranda, Warszawa 1846.

Literature

Adrianek M., Biblioteki publicznych szkót średnich Królestwa Polskiego w okresie międzypowstaniowym, "Folia Bibliologica" 2010, vol. 52, pp. 27-47.

Adrianek M., Książki szkolne w Królestwie Polskim w latach 1843-1863, "Folia Bibliologica" 1988/1989, vol. 36-37, pp. 49-77.

Androutso G. [i in.], Joseph-Claude-Anthelme Récamier (1774-1852): forerunner in surgical oncology, "Journal of BUON" 2011, vol. 16, pp. 572-576, [online] https:// www.researchgate.net/publication/51721295_Joseph-Claude-Anthelme_Recamier_1774-1852_Forerunner_in_surgical_oncology [retrieved on 24.05.2018].

Bielecki R., Encyklopedia wojen napoleońskich, Warszawa 2002.

Bielecki R., Wielka armia Napoleona, $2^{\text {nd }}$ edition revised and completed, Warszawa 2004.

Cabanis J., Karol X. Król-ultras, transl. W. Dłuski, Warszawa 1981.

Cichoń P., Wptywy francuskie w administracji Księstwa Warszawskiego, "Zeszyty Naukowe Uniwersytetu Jagiellońskiego. Prace Historyczne” 2013, vol. 140, no. 1, pp. 1-18.

Dawne antykwariaty warszawskie, [eds. J. Jęśko, J. Myszkowska], Warszawa 2003.

Dobrzański J., Szkolnictwo w Królestwie Polskim w roku szkolnym 1839, "Rocznik Lubelski” 1960, vol. 3, pp. 253-274.

Dunin-Wąsowicz K., Francuzi w Polsce. Podróże do kraju pod zaborami, Warszawa 2000.

Gerber R., Szkolnictwo Królestwa Polskiego w pierwszym dziesięcioleciu rządów Paskiewicza, "Rozprawy z Dziejów Oświaty" 1959, vol. 2, pp. 167-197.

Golka B., M. Kafel, Z. Kłos, Z dziejów drukarstwa polskiego, Warszawa 1957.

Hass L., Sekta farmazonii warszawskiej. Pierwsze stulecie wolnomularstwa $w$ Warszawie (1721-1821), Warszawa 1980.

Historia Europy, ed. by A. Mączak, Wrocław 1997. 
Historia życia prywatnego. Vol. 4: Od rewolucji francuskiej do I wojny światowej, ed. by M. Perrot, developed by A. Corbin [et al.]; translated from French language by A. Paderewska-Gryza, B. Panek, W. Gilewski; scientific edition of translation of the $4^{\text {th }}$ volume M. Czapliński, Wrocław 2006.

Horoszewicz M., Orgelbrandiana w zbiorach Muzeum Drukarstwa Warszawskiego, “Almanach Muzealny” 2014, vol. 8, pp. 289-311.

Kamiński K., Materiały do życia i twórczości Włodzimierza Wolskiego, "Pamiętnik Literacki” 1974, vol. 65 , no. 1 , pp. 143-169.

Klukowski B., Samuel Orgelbrand - ksiegarz, wydawca, drukarz. Dwusetna rocznica śmierci, "Poradnik Bibliotekarza" 2010, no. 12, pp. 3-6.

Kordala T., Generat Wojska Polskiego Piotr Bontemps (1777-1840), polski ziemianin z Francji rodem, Płock 2017.

Kowalczyk K., Księgarstwo warszawskie w drugiej połowie XIX wieku, Warszawa 2006.

Kula E., Naukowa, literacka i artystyczna twórczość nauczycieli rządowych męskich szkót średnich Królestwa Polskiego w latach 1833-1862, Kielce 2006.

Kuna M., Drukarnia, księgarnia i wydawnictwa Samuela Orgelbranda (1810-1868),"Przegląd Biblioteczny" 1955, no. 3-4, pp. 309-313.

Kurzawa T., Rola oficerów-wolnomularzy w okresie Księstwa Warszawskiego, [online]

https://repozytorium.amu.edu.pl/bitstream/10593/169/3/Rola\%20oficer\%C3\%B3w.\%20 Kurzawa\%20Tomasz.pdf [retrieved on 06.01.2018].

Lech M., Księgarze i księgarnie w Królestwie Polskim 1869-1905. Materiaty ze źródel archiwalnych, Warszawa 1980.

Lewandowski S., Powstanie przedsiębiorstwa Samuela Orgelbranda (1830-1868), "Rocznik Warszawski” 1971, vol. 10, pp. 113-141.

Łojek J., Opinia publiczna a geneza Powstania Listopadowego, Warszawa 1982.

Łoza S., Rodziny polskie pochodzenia cudzoziemskiego osiadte w Warszawie i okolicach. [Vol.] 1, Warszawa 1932.

Małachowski-Łempicki S., Wykaz polskich lóż wolnomularskich oraz ich członków w latach 1738-1821 poprzedzony zarysem historii wolnomularstwa polskiego i ustroju Wielkiego Wschodu Narodowego Polskiego, Kraków 1929.

Massalski A., Nauczyciele języka francuskiego męskich szkół średnich rządowych Królestwa Polskiego w latach 1833-1862, "Studia Pedagogiczne. Problemy Społeczne, Edukacyjne i Artystyczne" 1983, no. 14, pp. 55-81.

Mlekicka M., Wydawcy książek w Warszawie w okresie zaborów, Warszawa 1987.

Poznański K., Kursy dodatkowe pedagogiczne w Warszawie 1836-1848, "Rozprawy z Dziejów Oświaty” 1978, vol. 21, pp. 15-53.

Poznański K., Oświata i szkolnictwo w Królestwie Polskim 1831-1869. Lata zmagań i nadziei. Vol. 3: Polityka oświatowa caratu w latach 1834-1861, Warszawa 2004.

Regnaud de Saint-Jean d'Angély, Auguste, Comte, [online] https://www.napoleon.org/en/ history-of-the-two-empires/biographies/regnaud-de-saint-jean-dangely-auguste-comte/ [retrieved on 10.10.2018]. 
Romantycy $i$ Warszawa, ed. by S. Makowski, Warszawa 1996.

Schiller J., Nauczyciele szkół średnich Warszawy w pierwszej połowie XIX w.: szkic do portretu grupy zawodowej, "Rozprawy z Dziejów Oświaty” 1988, vol. 31, pp. 79-106.

Schiller J., Portret zbiorowy nauczycieli warszawskich publicznych szkót średnich 1795 1862, Warszawa 1998.

Skałkowski A., Bontemps Piotr (1777-1840), [in:] PSB. Vol. 2: Beyzym Jan-Brownsford Marja, Kraków 1936, pp. 305-306.

Słownik pracowników książki polskiej, ed. by I. Treichel, Warszawa-Łódź 1972.

Stownik społeczny, ed. by B. Szlachta, Kraków 2004.

Walka caratu ze szkoła polska w Królestwie Polskim w latach 1831-1870. Materiaty źródłowe, elaborated by K. Poznański, Warszawa 1994.

Whitteaker C. H., The Orginis of Modern Russian Education: an Intellectual Bipgraphy of Count Sergei Uwarow, Illionois 1984. [review] K. Bartnicka K, "Rozprawy z Dziejów Oświaty" 1993, vol. 33, pp. 245-248.

Wójtowicz M., Masoneria, Warszawa 2006.

Zajewski W., Jan Krukowiecki (1772-1850), [in:] PSB. Vol. 15: Kozłowska Zofia-Kubacki Stanisław, Wrocław 1970, pp. 392-397. 